\title{
Benchmarking as a management tool to reduce non-revenue water
}

\author{
Luis Otavio do Amaral Marques \\ Rafael Santos Carvalho \\ Marcelo Otani Marques de Sa \\ Tadeu Fabrício Malheiros
}


ring, University of São Paulo, São Carlos SP, Brazil.

"São Carlos School of Engineering, University of São Paulo, São Carlos SP, Brazil.

III São Carlos School of Engineering, University of São Paulo, São Carlos SP, Brazil.

Iv São Carlos School of Engineering, University of São Paulo, São Carlos SP, Brazil.

\begin{abstract}
In concerns of non-revenue water in water supply systems, the benefits arising from the reduction of their indexes directly impact social, economic and environmental spheres, including the expansion of access to clean water. Benchmarking is a management tool already adopted by some countries in this context, aiming to reduce the amount of non-revenue water. The present study aimed to gather information about the application models of this tool, as well as to compare the performance with other countries in which it is also not applied. It was observed that the ideal benchmarking structuring model capable of minimizing these indexes includes less than annual application frequency, partial regulation, absence of confidentiality, gratuity, open and restricted reports to service providers and mean interactivity of the results release. It was also concluded that the countries where benchmarking is practiced have better performances regarding lower levels of non-revenue water.
\end{abstract}

Keywords: Water supply system; non-revenue water; performance improvement; benchmarking.

São Paulo. Vol. 24, 2021

Special Issue: Sustentare and International Workshop on Sustainability Indicators (WIPIS)

DOI: http://dx.doi.org/10.1590/1809-4422asoc20200025vu2021L4DE 


\section{Introduction}

Being one of the core topics of the United Nations' Sustainable Development Goals (SDG), nowadays drinking water is recognized worldwide as an essential resource, however vulnerable, limited and increasingly scarce, a situation which is impaired by factors such as increase in demand, pollution of water sources and increasingly severe climate changes (GOONETILLEKE \& VITHANAGE, 2017; BEZERRA, PERTEL \& MACÊDO, 2019). For McDonald et al. (2014) such a scenario is also the result of strong global urbanization movement without the necessary planning, related to water availability in the surroundings of cities to supply water to the populations, as well as to the management of residues produced by such cities.

According to Jacobi, Empinotti \& Schmidt (2016), in 2016 over a billion people did not count on proper access to drinking water and forecast in the short run is that hydric stress will affect over $40 \%$ of the world population, an estimate that illustrates the dimensions of current and future problems related to access to quality water and the management of existing public [water] supplies.

In this sense, within the context of water supply systems, non-revenue water represents one of the main challenges faced and is among the supply systems key efficiency indicators. Integrated management and control of losses shall always be part of the agenda of efforts of providers and management entities (SOBRINHO \& BORJA, 2016).

However, in spite of consensus about their importance, average indexed losses in many countries, as well as other sanitation indexes, show severe disparity, and there are places such as Denmark and the Netherlands where the percentages of losses are under 10\% (LIEMBERGER \& WYATT, 2018) and countries like Brazil, where such indexes are close to $40 \%$ (ITB, 2018).

For Kusterko et al. (2018), the reduction of such losses is part of a context strongly related to strategic planning and decision-making on the part of those responsible for sanitation, being an extremely important factor for providers' sustainability and competitiveness and, therefore, for the improvement in the provision of services, representing benefit in various segments: energy, economic, sociocultural and technological segments. Thus, the need to invest not only in the conception of new efficient technologies, but also in addressing efforts for the development and improvement of mechanisms to apply such technologies and the management of sanitation, in its different areas, is clear.

Benchmarking is a process already adopted in some locations in this context and is set up as the sharing of practices among companies and institutions, the performance indexes of which are in a superior level, for a possible adoption with adjustments by those companies having lower performance indexes, being thus considered an interesting improvement and management tool (PETENATE, 2019).

Hence, so as to improve the knowledge about the application of benchmarking to sanitation systems, the purpose of this essay is to gather information about the application of such practice by those entities in charge of sanitation services and make an analysis of its relation to the performance referring to control of losses in water supply systems. 


\section{Non-revenue water and Benchmarking}

According to Cardoso (2002), performance indicators are important management instruments, capable of providing an objective view of the procedures involved in a certain process, being used to obtain overviews and increase efficiency. As related to the provision of public water supply services there is a significant number of quali-quantitative indicators capable of evaluating the operation. Currently, one of such indicators receiving large attention is that of physical non-revenue water, closely related to hydric balance.

Hydric balance is one of the tools used to quantify the performance of a water supply system. As from the collection process, including the treatment phase, to its effective distribution, water has one part the consumption of which may be authorized, and another part constituted by non-revenue water corresponding to the difference between the initial volume and the authorized volume, whether measured or estimated (ITB, 2018).

According to the International Water Association (IWA), the international entity in charge of helping several countries to manage their hydric resources, non-revenue water in the supply system may be of actual (physical) losses, or apparent losses (turnover losses). The volume of water lost due to leakage, as from the collection up until the distribution, and due to procedures having an excessive consumption of such resource, such as filter washing, constitute physical water losses (ABES, 2015). When dealing with issues related to fraud or illegal systems and measurement issues, those are defined as turnover losses, being directly incumbent to service providers (SILVA et al., 1998).

We know that a water distribution network without losses is not something technically and economically feasible, as part of the losses are due to the very technical limitations of the systems (unavoidable losses) but concentrating efforts so that there is a limited volume of loss is a possible and beneficial task for society as a whole (ITB, 2018).

Figure 1 illustrates the determination of the economic level of physical losses for a drinking water supply system, generally defined as being of 15\% (ITB, 2018). Several countries are still far from achieving such economic level of non-revenue water, showing the need of measures, especially management measures (SANTI, 2018), that tackle such problem.

In that respect, the sharing of information among the service providing companies is considered an important tool to improve performance. Moreover, this process is already applied worldwide in other types of entities, being designated as benchmarking (PETENATE, 2019).

Benchmarking is a tool the focus of which is to increase the performance of a certain company, by comparing it to a reference model. It was first applied in Japan in the seventies but achieved worldwide importance due to the increasing and constant need of entities to become more competitive, with optimized processes, in face of the increase in competition (CARPINETTI, 2016).

However, benchmarking does not consist in the "copying and pasting" of a model, once each entity exercises different functions in different intensities and manners, it being necessary to adjust the practice applied in different environments, thus constituting 
a learning process rather than plagiarism, what would remove any legitimacy from the entities.

In addition, it is worth highlighting that the adoption of such practice is based on the principle that there is no company having the best performance rates in all aspects; therefore, its adoption consists in a beneficial process for all those participating, in which collaborators may share information with a view to improving performance (ALEGRE, 1994).

Figure 1 - Costs related to the number of leaks.

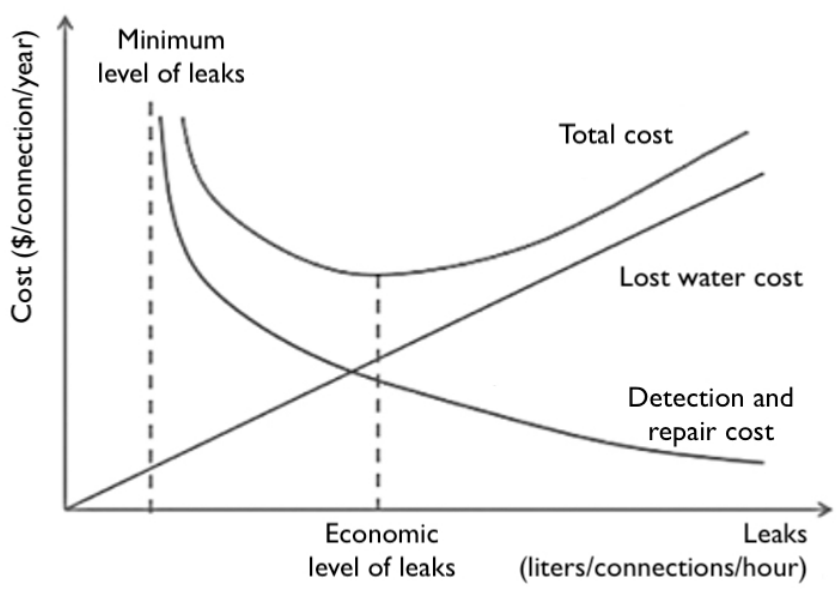

Source: ITB, 2018.

In the water supply area, there are many studies that give scientific support to positive results of benchmarking as an important tool to make decisions and increase productivity and quality, as those performed by McCormack (2005) and Köelbl (2008).

Therefore, the application of such tool in the sector allows the comparison of management and infrastructure aspects, such as processes adopted and the observation of impacts of strategical decisions in improvements, in addition to simulating competitive environments, identifying and measuring inefficiencies (SEPPÄL $\ddot{A}, 2015$; ROMERO and FERRO, 2008). Its use is seen in several countries for such purpose; in some of them benchmarking is, moreover, mandatory and regulated by federal governments.

\section{Methodology}

This article is a gathering of information by collecting and analyzing different models of application of benchmarking as a tool to improve the performance of water supply systems on international level. 
The locations were chosen based on highlighted items mentioned by Cabrera (2014) in his book Benchmarking Water Services: Guiding Water Utilities to Excellence. The structuring of benchmarking application required more detailed searches, in scientific platforms as well as in the very web pages of each local institution in charge of the tool practice in the area.

To do so, qualitative aspects related to the implementation of the practice in each location were defined, so that at the end it was possible to obtain a model in which nonrevenue water is minimized and its application may be directed in location where it is not applied yet, adapting the tool, naturally, to the circumstances of the country.

Such aspects are: frequency of use of the exercise (that may be annual or less frequent), regulation (mandatory participation due to legislation in effect or voluntary participation), decade in which the activities started, confidentiality as related to the name of each water supply service provider in the final products (absent or total), costs (gratuity, billing or partial gratuity) final product (reports that may be public and/or private, private digital platforms), interactivity of the final product with the user (high, average or low).

Finally, the average annual indexes of physical losses of water of all countries in the world are compared after having been divided among reference locations in the use of benchmarking (in this study) and all others.

\section{Systematic Application of Benchmarking}

\subsection{The Netherlands}

The Netherlands are pioneers in the use of benchmarking in this area worldwide. Its first application was carried out in the eighties, as internal comparison of practices of different companies, and the results were confidential to those participating. In the nineties there was the first practice of benchmarking of public domain, with voluntary participation of service providers. In 2012, a federal law made the practice of benchmarking by service providers mandatory. Until present days, $35 \%$ of improvement in efficiency of the companies was observed, thus justifying the importance given by the public sector to related practices (GOEDE, 2016). "I can only conclude that benchmarking works!", stated the Dutch prime minister of Housing, Urban Planning and Environment in her speech to the International Water Association (CRAMER, 2007).

In the Netherlands, the benchmarking applied to supply water is published by the Association of Dutch Water Companies (Vereniging van drinkwaterbedrijven in Nedelan - VEWIN) in the form of reports of federal coverage each two or three years. In such documents, which values refer to which companies are explicit. There are also private comparative reports, sent to each one of the ten water service providers in the country, with more detailed information and specifying the position of a company in relation to the other companies, whose names are not specified in such documents (BLOKLAND, 2010). The public reports are also available as an interactive version in the web page of the Water Companies Union (WAVES). 


\subsection{Germany}

In this country, benchmarking has been present for almost 20 years and in over 800 public and private providers (RÖDL, 2020), being characterized by the guarantee of anonymity and safety of the data supplied and by voluntary participation on the part of service providers, present in most studies in view of potential improvement of services. There is support and incentive from the government for its realization.

The structuring of benchmarking is made through state reports in which there are indicators that may vary according to the state, but always divided into five areas: economic efficiency, supply quality, reliability of supply, customer service and sustainability. Such documents are issued annually and are made available online, as a public report. There is always an understanding in such reports that the results of each indicator are in state level (VEWSAAR, 2017).

\subsection{Portugal}

Benchmarking in sanitation area in Portugal is made with the mandatory participation of all service provider companies in the country, once the reports are part of public policies of improvement of sanitary services adopted by the country government. The use of indicators that evaluate the water distribution system dates back to the end of the nineties. (ALEGRE and COELHO, 1997).

In 2005, the Water and Residue Regulatory Institute (Instituto Regulador de Águas e Resíduos - IRAR) considered as necessary the regulated yearly publication of the reports with a sanitary panorama in the country. In one of them there is a chapter designated as "Evaluation and benchmarking of the quality of service provided to customers", in which we can note that the incorporation of this tool through the comparison of indicators of service providers is made in an explicit manner, without confidentiality. We also note that for each indicator there is a comparison of the weighted average of such indicator with the results of the previous years, showing the evolution of the service in the country as a whole.

The data that constitute such reports are also made available to the public on the web page of the Water and Residue Services Regulatory Entity (Entidade Reguladora dos Serviços de Águas e Resíduos - ERSAR) as an electronic spreadsheet (Microsoft Excel), that may be used to analyze various types of various agents (ERSAR, 2020). However, we can note that the number of indicators is low in comparison with that of other countries where the participation is optional.

\subsection{Austria}

The Austrian Association for Gas and Water (Österreichische Vereinigung für das Gas- und Wasserfach - ÖVGW) has conducted since 2002 benchmarking projects in the water supply area. The results of the pilot project dated 2004 were published in 
two types of report: a public one and an individual one for each participating company (NEUNTEUFEL et. al, 2004). The data provided is confidential and may be used in researches by the Vienna University of Natural Resources and Nature Sciences and the Graz Technical University, partners in the Project. The participation is voluntary and with the payment of a fee, the minimum value of which is of 1950 Euros.

The frequency of projects is not defined. Until this date, only five projects have been made, in the years of 2002, 2004, 2007, 2012 and 2015. The reports are made based on two important aspects: confidentiality and transparency. In such reports, the amounts discriminated by the company are not explicit, only a general statistic view of the participants, as well as comparisons with the average values of external projects of sanitary benchmarking, such as that of the State of Bayern (Germany) and EBC Foundation (Europe).

\subsection{Denmark}

The Danish Water and Wastewater Association (DANVA) has a program designated as "DANVA Benchmarking", of voluntary participation and that has started with a pilot study in 2001, involving some sanitation companies. The results were confidential until the year of 2004 , as from then a public report has been made available yearly. Also, in this year the data collection processes, and the provision of compared data were made fully available online, through an access platform restricted to the participating institutions. The entry of data may be made at any time and the indicators are updated simultaneously, thus making it a dynamic platform. The yearly public reports have not been discontinued and are still made available.

As from 2008 and 2010, respectively, the sharing of data about economic efficiency and performance related to environmental parameters with public sectors that regulate sanitation have become mandatory as required by law, in actions designated as "TOTEX Benchmarking" and "Performance Benchmarking". The "DANVA Benchmarking" program has continued to exist, addressing various other aspects of the area. Participation in this program has continued to be voluntary, by paying a yearly fee of 1500 Euros (DANVA, 2020).

\subsection{Canada}

The benchmarking model applied to the sanitation area in this country is part of the National Water and Wastewater Benchmarking Initiative (NWWBI), the activities of which have started in 1998 and, since then, has increased in participation of service providers reaching over 50 participating companies, responsible for the water supply of over $70 \%$ of the Canadian population. It is the initiative of an American private engineering company (AECOM) and it is not free of charge (AECOM, 2018).

A digital platform yearly updated with financial and operational indicators of the service providers is used, which are verified by field visitation. Participation is voluntary 
and the information provided is commercially confidential, thus restricting the access to the active platform to the participating members, who are also provided with private reports detailing their performance as compared to that of the other members. There are some public reports available at the NWWBI site, referring to random years, without following a publication frequency. It is known that there are also yearly workshops organized by this same institution, in which the participants may discuss directives and results of benchmarking in the country's sanitation area (NWWBI, 2013).

\subsection{United States of America}

The American Water Works Association (AWWA) acknowledges the importance of benchmarking in sanitation area and, therefore, it has a program in which performance indicators are compared to those of the participating institutions, so as to identify the areas which may be improved. Participation is through a survey that collects data from the participating institutions yearly, which are later provided with a free report about the performance of each institution as compared to the area average.

Access to more detailed information, with historical values of each indicator may be acquired by purchasing the yearly benchmarking report in sanitation. Those participating in the survey in a certain year are entitled to a discount to purchase the report, having to pay an amount of 399 US Dollars. For 570 US Dollars, any natural or corporate person may have access to the report, in which the names of the participating companies together with their performance indicators are kept confidential (AWWA, 2020).

\subsection{European Benchmarking Cooperation Foundation}

The European Benchmarking Cooperation Foundation (EBC Foundation) is a self-styled nonprofit institution, that establishes the use of benchmarking in the sanitation area in predominantly European countries by offering its Benchmarking Program.

This program consists in the provision of exclusive reports in which there is a comparison of [the company's] performance to that of the other participating institutions, without clarifying which data refer to which companies, but only [clarifying] that of the company receiving the report. There is also a public report that is made available yearly, with general indicators.

Moreover, access to a benchmarking online platform is offered to the participating institutions, with the same confidentiality criteria as that of the written reports provided to the companies. In this platform there are water service indicators that may be accessed and the exportation of historical data and browsing in such platform is considered easy and stimulating. (EBC, 2020).

So as to access the services mentioned above, the participating companies have to execute an agreement with $\mathrm{EBC}$, in which they undertake to pay for the service chosen.

\section{Comparison of Qualitative and Quantitative Aspects}


Table 1 shows a comparative summary of the qualitative aspects referring to the benchmarking application models to water supply systems adopted by the locations mentioned above, reference in terms of adoption of such practice to improve performance in the area. The average physical losses of water in such systems for the year of 2018 can also be observed.

Table 1 - Comparison of benchmarking models applied in selected locations.

\begin{tabular}{|c|c|c|c|c|c|c|c|c|}
\hline Location & $\begin{array}{l}\text { Fre- } \\
\text { quency }\end{array}$ & $\begin{array}{l}\text { Regula- } \\
\text { tion }\end{array}$ & $\begin{array}{l}\text { Start of } \\
\text { activities }\end{array}$ & $\begin{array}{l}\text { Confiden- } \\
\text { tiality }\end{array}$ & Costs & $\begin{array}{l}\text { Final } \\
\text { Product }\end{array}$ & $\begin{array}{l}\text { Interac- } \\
\text { tivity }\end{array}$ & $\begin{array}{l}\text { Non- } \\
\text { revenue } \\
\text { water }\end{array}$ \\
\hline $\begin{array}{l}\text { The } \\
\text { Nether- } \\
\text { lands }\end{array}$ & Lower & $\begin{array}{l}\text { Regula- } \\
\text { ted }\end{array}$ & 1980's & Absent & Free & $\begin{array}{l}\text { Public } \\
\text { and } \\
\text { private } \\
\text { reports }\end{array}$ & Average & $5 \%$ \\
\hline Denmark & Yearly & $\begin{array}{l}\text { Partially } \\
\text { regulated }\end{array}$ & 2000's & Absent & $\begin{array}{l}\text { Partially } \\
\text { free }\end{array}$ & $\begin{array}{l}\text { Public } \\
\text { and } \\
\text { private } \\
\text { reports } \\
\text { and } \\
\text { private } \\
\text { digital } \\
\text { platform }\end{array}$ & High & $7 \%$ \\
\hline Germany & Yearly & $\begin{array}{l}\text { Volun- } \\
\text { tary }\end{array}$ & 2000's & Total & $*$ & $\begin{array}{l}\text { Public } \\
\text { report }\end{array}$ & Low & $15 \%$ \\
\hline Austria & Lower & $\begin{array}{l}\text { Volun- } \\
\text { tary }\end{array}$ & 2000's & Total & Charge & $\begin{array}{l}\text { Public } \\
\text { and } \\
\text { private } \\
\text { reports }\end{array}$ & Low & $15 \%$ \\
\hline Canada & Lower & $\begin{array}{l}\text { Volun- } \\
\text { tary }\end{array}$ & 1990's & Total & Charge & $\begin{array}{l}\text { Public } \\
\text { and } \\
\text { private } \\
\text { reports } \\
\text { and } \\
\text { private } \\
\text { digital } \\
\text { platform }\end{array}$ & High & $15 \%$ \\
\hline Portugal & Yearly & $\begin{array}{l}\text { Regu- } \\
\text { lated }\end{array}$ & 1990's & Absent & Free & $\begin{array}{l}\text { Public } \\
\text { report }\end{array}$ & Low & $18 \%$ \\
\hline USA & Yearly & $\begin{array}{l}\text { Volun- } \\
\text { tary }\end{array}$ & $*$ & Total & $\begin{array}{l}\text { Partially } \\
\text { free }\end{array}$ & $\begin{array}{l}\text { Private } \\
\text { report }\end{array}$ & Low & $20 \%$ \\
\hline
\end{tabular}




\begin{tabular}{|l|l|l|l|l|l|l|l|l|}
\hline Location & $\begin{array}{l}\text { Fre- } \\
\text { quency }\end{array}$ & $\begin{array}{l}\text { Regula- } \\
\text { tion }\end{array}$ & $\begin{array}{l}\text { Start of } \\
\text { activities }\end{array}$ & $\begin{array}{l}\text { Confiden- } \\
\text { tiality }\end{array}$ & Costs & $\begin{array}{l}\text { Final } \\
\text { Product }\end{array}$ & $\begin{array}{l}\text { Interac- } \\
\text { tivity }\end{array}$ & $\begin{array}{l}\text { Non- } \\
\text { revenue } \\
\text { water }\end{array}$ \\
\hline $\begin{array}{l}\text { EBC } \\
\text { Founda- } \\
\text { tion }\end{array}$ & Yearly & $\begin{array}{l}\text { Volun- } \\
\text { tary }\end{array}$ & 2000's & Total & Charge & $\begin{array}{l}\text { Public } \\
\text { and } \\
\text { private } \\
\text { reports } \\
\text { and } \\
\text { private } \\
\text { digital } \\
\text { platform }\end{array}$ & High & $24 \%$ \\
\hline & & & & & & & & \\
\hline
\end{tabular}

Source: Own elaboration, 2021.

*: no data.

Figure 2 was prepared with a view to obtaining an ideal model to structure the qualitative aspects of the application of benchmarking in water supply systems, based on the lower losses of the countries in Table 1.

Figure 2 - Water losses according to the qualitative aspects.

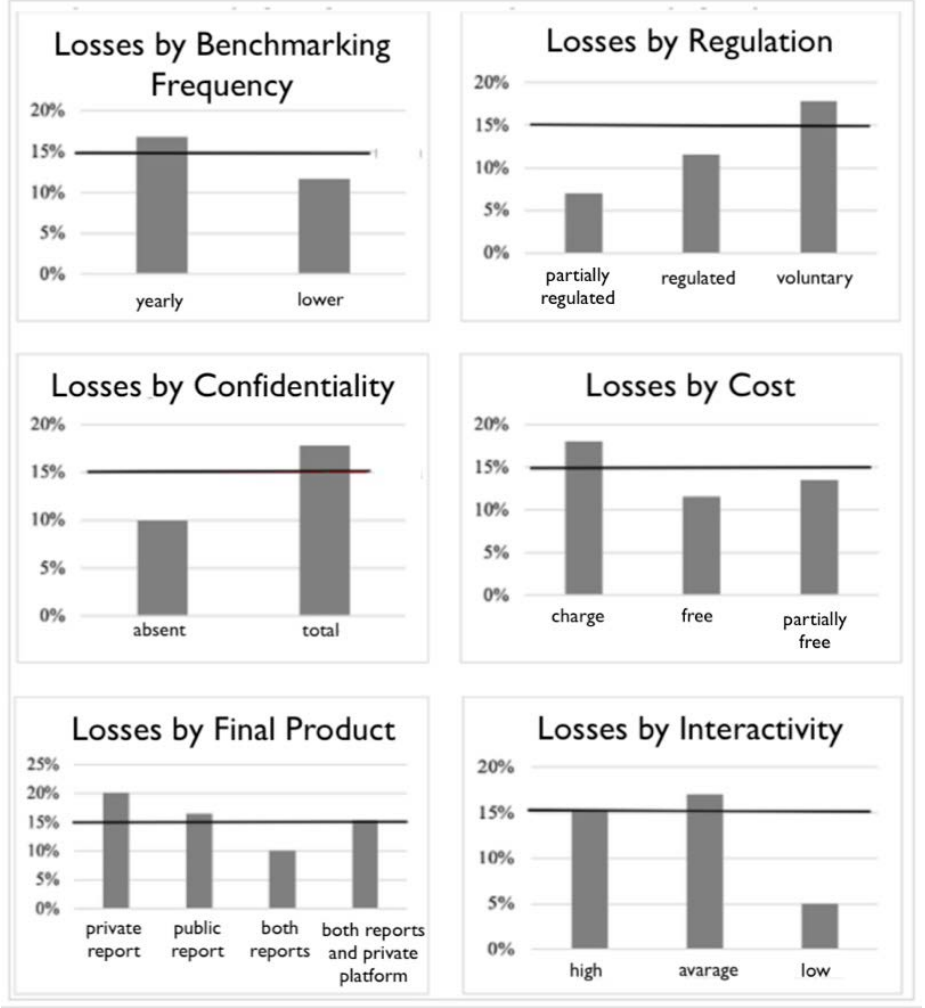

Source: Own elaboration, 2021. 
According to the charts in Figure 2, the models showing the best performance in minimizing non-revenue water include frequency in applying such tool lower than once a year, partial regulation, no confidentiality, free of charge, public and private reports to the service providers and average interactivity as related to showing practical results.

However, it is important to mention that, although those are prominent locations in terms of use of this tool in water supply systems, the sample space is still low to be able to infer that a structuring in these models is in fact the ideal to be pursued. Also due to the fact that each location has its own characteristics, laws and circumstances, which inevitably interfere in the process.

Nevertheless, as benchmarking refers to the adoption of external practices that were successful and the respective adaptation to the reality of those who are implementing it, the structure mentioned above still represents a guiding mechanism for a location which is planning to apply the tool so as to improve performance, especially as related to non-revenue water in supply systems.

\section{Influence of Adopting Benchmarking in Indexed Losses}

It can be observed that the average percentage of non-revenue water taking into consideration the locations in Table 1 is of exactly $15 \%$, a value considered by the International Water Association (IWA) as economic for such index, taking into account the costs to detect and repair losses and the non-revenue water itself.

It should be highlighted that developed countries have better conditions to address the loss issue, as they have more resources and that is the case of most countries in the locations mentioned in Table 1.

However, it should be mentioned that the adoption of benchmarking as a tool to improve performance, not only as related to non-revenue water, contributes for those results to be optimized as they are nowadays, in addition to providing many of such locations with more transparency in the water supply service to its population.

Figure 3 shows the contribution of benchmarking as a tool to improve performance as related to physical losses of water, so far as it compares the average values of loss for 223 countries worldwide in the year of 2018, according to data gathered by Liemberger and Wyatt (2018). 
Figure 3 - International comparison of water losses highlighting the use of benchmarking as a performance improvement tool in 2018.



Source: Liemberger and Wyatt (2018).

\section{Brazilian Scenario and Perspectives}

Brazil lacks concrete and accessible initiatives that stimulate benchmarking with the country's service providers, once there are no free platforms or reports developed by the regulatory entities, in which to see the practice, although such practice has been emphasized in researches applied to this area (CETRULO, 2019).

In the academic context, there are studies involving benchmarking techniques in the analysis of characteristics of the sanitation area in the country, such as that of Santi (2018), in which, through the application of such techniques, the performance of sanitation companies with reference to non-revenue water was evaluated. Coelho (2004) used benchmarking to analyze the relation between efficiency of the sanitation providers' registration systems and its respective non-revenue water indexes. Guimarães (2013) analyzed the different regulatory approaches applied to the tariff reviews over benchmarking indicators within the Brazilian context, more specifically in the state of São Paulo.

In practical terms, we may mention the National Sanitary Quality Prize (Prêmio Nacional de Qualidade em Saneamento - PNQS), established in 1997 by the Brazilian Association of Sanitary Engineering (Associação Brasileira de Engenharia Sanitária - ABES) to be awarded every year to the companies distinguished by good service management in this sector. It is a contest for cases of voluntary participation of service providers and 
paid with enrollment fees that vary between $6-7$ thousand reais and 80 thousand reais. There is a report that allows the comparison of awarded participants through indicators, in addition to prizes to key participants in practices that vary according to the enrollment category. Days before the award ceremony there is the Benchmarking Seminar, when some of the awarded institutions may share their successful cases with the other participants (PNQS, 2020). In addition, the Brazil Benchmarking Program (Programa Benchmarking Brasil - PBB), that existed until 2013, organized by the private company Mais Projetos Corporativos (MPC), and that offered a sustainability seal for the best social-environmental practices to Brazilian institutions. PBB lasted for over a decade and had Senior, Junior and Hackathon categories (MPC, 2013). The enrollment of projects was free and online, but there were financial compensations for cases achieving marks for benchmarking certification.

In view of the need of Brazilian initiatives going beyond prize awards and that may possibly come into practice in the manner as regulated by entities in the water supply sector, it is of utmost importance to carry out development and feasibility studies of benchmarking tools.

The constructions and operationalization of a digital platform for the sharing of information, for instance, is a challenge that may result in large performance improvements not only in relation to non-revenue water, but also as related to other aspects. It would be ideal if such platforms were open, in spite of some mentioned in Table 1, in view of the fact that closed platforms, although they are useful for the sharing of information, make research and transparency difficult. Therefore, we suggest that the development of a digital benchmarking platform would include non-revenue water issues and be accessible. Such platform could even be used with a pedagogical perspective, as a learning tool for the exchanging information among its users, and it could even be included in forums and on-line courses related to the subject.

\section{Conclusions}

In view of the foregoing, we conclude as from the gathering of information about benchmarking in the different locations where it is applied, included in this essay, that the form of execution of this process presents variations as related to the frequency of application, regulation, confidentiality, among other aspects, it being also possible to conclude, as from the analysis of such variations, that the combination of qualitative aspects of different models would constitute the ideal model related to lower indexed losses.

Even though it may be necessary to consider the influence of different levels of development in the location in a worldwide context, it is also valid to conclude that countries where benchmarking was adopted for sanitation systems present better indexes related to non-revenue water, indicating a relation between such process and better levels of performance.

It is therefore recommended that more and more Brazilian entities related to the water supply sector adopt benchmarking as a tool to improve performance, thus creating 
models with structures that meet the needs of each region.

Thus, the goals intended by this essay were achieved, so much for the collecting and gathering of information about models to apply benchmarking to water supply systems, as for possible relations with the performance of countries in controlling losses. It should be highlighted, among the difficulties faced in this study, the difficulty to obtain data not only about the structure to apply the tool, but also about the performance indexes in different locations. A deeper analysis is further recommended related to loss indicators and other aspects of sanitation with the application of benchmarking as a tool in international context.

\section{Acknowledgments}

The authors would like to thank the Coordination for the Improvement of Higher Education Personnel (Coordenação de Aperfeiçoamento de Pessoal de Nível Superior - CAPES) and the National Council of Scientific and Technological Development (Conselho Nacional de Desenvolvimento Científico e Tecnológico - CNPq) for the financing of the researches that resulted in this article. Our deepest and most sincere acknowledgment to Universidade de São Paulo, more specifically the Hydraulic and Sanitation Department of the São Carlos Engineering College, for the academic infrastructure. In addition, our thanks to the II Sustentare and V WIKIS events, for having recommended and funded the publication. Finally, we thank the whole team of collaborators of the Environment and Society Magazine (Revista Ambiente e Sociedade), as well as the ad hoc advisors, for the thorough and positive evaluation and feasibility of this article.

\section{References}

ABES - Associação Brasileira de Engenharia Sanitária e Ambiental. Controle e redução de perdas nos sistemas públicos de abastecimento de água - posicionamento e contribuições técnicas da ABES. Revisão 1. Rio de Janeiro, 2015.

AECOM. Public Report - Canadian National Water \& Wastewater Benchmarking Initiative. Los Angeles, 2018.

ALEGRE, H. Instrumentos de apoio à gestão técnica de sistemas de distribuição de água. Vol. I da série “Teses e Programas de Investigação LNEC”, LNEC, Lisboa, 1994.

ALEGRE, H. COELHO, S.T. Indicadores de desempenho de sistemas de saneamento básico, projeto financiado pela Direcção-Geral do Ambiente, relatório final, LNEC, Lisboa, 1997.

AWWA - Associação Americana de Trabalhos com Água. The Benchmarking Program. Denver, United States, 2020. Disponível em: < https://www.awwa.org/Resources-Tools/Programs/ Benchmarking >. Acesso em: out. 2020. 
BEZERRA, S. T. M.; PERTEL, M.; MACÊDO, J. E. S. Avaliação de desempenho dos sistemas de abastecimento de água do Agreste brasileiro. Ambient. Constr., v.19, n.3, 2019.

BLOKLAND, M.W. "Benchmarking Water Services Delivery", in M. Kurian and P. McCarney (eds.) "Peri-urban Water and Sanitation Services: Policy, Planning and Method". Springer Verlag. Berlim, Alemanha, 2010.

CABRERA, E.; DANE, P.; HASKINS, S.; FRITZ, H. TH. Benchmarking para servicios de agua: Guiando a los prestadores de servicios hacia la excelencia. Editorial Universitat Politècnica de València. 2014.

CARDOSO, A. L. Indicadores de Gestão Urbana: Projeto BRA/00/24. SEDU/PR-PNUD Sistema Nacional de Indicadores Urbanos. Brasília: SEDU/PRPNUD, 2002.

CARPINETTI, L. C. R. Gestão da qualidade. Cap. 11. GEN-Atlas. São Paulo, 2016.

CETRULO, T. B.; MARQUES, R. C; MALHEIROS, T. F. An analytical review of the efficiency of water and sanitation utilities in developing countries. Water Research, v. 161, p. 372-380, 2019.

COELHO, F. J. M. Estudo de Sistemas Cadastrais de Empresas de Saneamento através de Benchmarking. Recife, 2004, 99p.

CRAMER, J. Speech at International Water Association. Amsterdam, 2007. Disponível em: <http://www.vrom.nl/pagina.html?id=34253>. Acesso em: out. 2020.

DANVA - Agência Dinamarquesa de Água e Esgoto. Benchmarking og Statistik. Kopenhagen, 2020. Disponível em: < https://www.danva.dk/publikationer/benchmarking-og-statistik/>. Acesso em: out. 2020.

EBC - Fundação Europeia de Cooperação em Benchmarking. Participation and practicalities. 2020. Disponível em: < https://www.waterbenchmark.org/content/the-programme-explained participation-and-practicalities $>$. Acesso em: out. 2020.

ERSAR - Entidade Reguladora dos Serviços de Águas e Resíduos. Relatório Anual dos Serviços de Águas e Resíduos em Portugal (RASARP). Volume 1 - Caraterização do setor de águas e resíduos. Lisboa, 2020.

GOEDE, M. DE; ENSERINK, B.; WORM, I.; VAN DER HOEK, J.P. Drivers for performance improvement originating from the Dutch drinking water benchmark. Water Policy, Uncorrected Proof. 2016.

GOONETILLEKE, A.; VITHANAGE, M. Water Resources Management: Innovation and Challenges in a Changing World. Water, v.9, n.281, 2017.

GUIMARÃES, E. F; TEMÓTEO, T. G.; MALHEIROS, T. F. Benchmarking aplicado às revisões tarifárias do saneamento. Revista DAE, n.192, 2013. 
ITB - Instituto Trata Brasil; Go Associados. Perdas de Água 2018 (SNIS 2016): Desafios para Disponibilidade Hídrica e Avanço da Eficiência do Saneamento Básico. São Paulo, 2018. Disponível em: < https://cebds.org/blog/escassez-de-agua/\#>. Acesso em out. 2020.

JACOBI, P. R.; EMPINOTTI, V. L.; SCHMIDT, L. Escassez hídrica e direitos humanos. Ambiente e Sociedade, v.9, n.1, 2016.

KÖELBL, J.; MAYR, H.; THEURETZBACHER-FRITZ, H.; NEUNTEUFEL, R.; PERFLER, R.; GANGL, G.; KAINZ, H.; HABERL, R. Experiences with Water Loss PIs in the Austrian Benchmarking Project. IWA Water Loss. Romania. 10 p. 2008.

KUSTERKO et al. Gestão de perdas em sistemas de abastecimento de água: uma abordagem construtivista. Eng. Sanit. Ambient., v.23, n.3, 2018.

LIEMBERGER, R.; WYATT, A. Quantifying the global non-revenue water problem. Water Science \& Technology Water Supply. 2018.

MCCORMACK, C. H. Canadian Utilities Learn to Fly through Benchmarking of Water Loss Management. IWA Leakage, Conference Proceedings. Halifax, Canada. 6 p. 2005.

MCDONALD, R. I. WEBER, K.; PADOWSKI, J.; FLÖRKE, M.; SCHNEIDER, C.; GREEN, P. A.; GLEESON, T.; ECKMAN, S.; LEHNER, B.; BALK, D.; BOUCHER, T.; GRILL, G.; MON. TGOMERY, M. Water on an urban planet: Urbanization and the reach of urban water infrastructure. Global Environmental Change, v.27, p.96-105, 2014.

MPC - Mais Projetos Corporativos. Quem Somos (Institucional). São Paulo, 2013. Disponível em: <http://maisprojetos.com.br/quem-somos/>. Acesso em: out. 2020.

NEUNTEUFEL, R.; KRAKOW, S.; PERFLER, R; FUCHS-HANUSCH, D. Abschlussbericht zum ÖVGW Benchmarking 2016. Wien/Graz, 2017.

NWWBI - Canadian National Water \& Wastewater Benchmarking Initiative. Dashboard. Vancouver, 2013. Disponível em: <https://www.nationalbenchmarking.ca/>. Acesso em: out. 2020.

PETENATE, M. O que é Benchmarking. 2019. Disponível em: < https://www.escolaedti.com. br/o-que-e-benchmarking >. Acesso em: out. 2020.

PNQS - Prêmio Nacional de Qualidade em Saneamento. Regulamento 2020. Rio de Janeiro, 2020. Disponível em: <http://pnqs.com.br/regulamento2020/>. Acesso em: out. 2020.

RÖDL \& PARTNER. Über das Benchmarking in der Wasserversorgung und Abwasserentsorgung. Nürnberg, Alemanha, 2020. Disponível em: <https:/www.roedl.de/benchmarking/ ueber-benchmarking >. Acesso em: out. 2020.

ROMERO, C. A.; FERRO, G. A. Benchmarking exercise on Latin American water Utilities. Buenos Aires: UADE - Universidad Argentina de la Empresa, v. 1, 2008. 
SANTI, A. D. Benchmarking aplicado ao controle das perdas de água no contexto das bacias hidrográficas Piracicaba, Capivarí e Jundiaí. São Carlos, 2018.

SEPPÄLÄ, O. T. Performance Benchmarking in Nordic water utilities. Procedia Economics and Finance, v. 21, n. 1, p. 399-405, 2015.

SILVA, R. T., CONEJO, J.G.L., MIRANDA, E.C. E ALVES, R.F.F. Indicadores de Perdas nos Sistemas de Abastecimento de Água - DTA A2. Programa de Combate ao Desperdício de Água - PNCDA, Ministério do Planejamento e Orçamento, Secretaria de Política Urbana, Brasília, 1998, 70p.

SOBRINHO, R. A.; BORJA, P. C. Gestão das perdas de água e energia em sistemas de abastecimento de água da Embasa: um estudo dos fatores intervenientes na RMS. Eng. Sanit. Ambient., v.21, n.4, 2016.

VEWSaar - União das Economias de Energia e Água do Estado de Saarland. Kennzahlenvergleich der saarländischen Unternehmen der Wasserversorgung: Ergebnisbericht 2017. Saarbrücken, 2017. 
Luis Otavio do Amaral Marques

$\varangle$ luis.otavio.marques@usp.br

ORCiD: https://orcid.org/0000-0001-6092-8773

Submitted on: 26/03/2021

Accepted on: 13/07/2021

2021;24e:0025

\section{Rafael Santos Carvalho}

$\checkmark$ rafaelcarvalho14@usp.com

ORCiD: https://orcid.org/0000-0002-4740-2766

\section{Marcelo Otani Marques de Sa}

$\checkmark$ marcelo.otani@usp.br

ORCiD: https://orcid.org/0000-0002-4024-6254

\section{Tadeu Fabrício Malheiros}

$\checkmark$ tmalheiros@usp.br

ORCiD: https://orcid.org/0000-0002-9455-4199

How to cite: MARQUES, L. O. A.; CARVALHO, R. S., SA, M. O. M., MALHEIROS, T. F. Benchmarking as a management tool to reduce non-revenue water. Ambiente $\mathbb{E}$ Sociedade. São Paulo, v. 24, p. 1-18, 2021. 


\title{
Benchmarking enquanto ferramenta de diminuição das perdas físicas em sistemas de abastecimento de água
}

\author{
Luis Otavio do Amaral Marques \\ Rafael Santos Carvalho \\ Marcelo Otani Marques de Sa \\ Tadeu Fabrício Malheiros
}

São Paulo. Vol. 24, 2021

Dossiê Especial:

Sustentare e Workshop Internacional sobre Indicadores de Sustentabilidade (WIPIS)
Resumo: No contexto das perdas em sistemas de abastecimento de água, os benefícios oriundos da redução de seus índices influenciam diretamente em questões sociais, econômicas e ambientais, incluindo a universalização dos serviços de saneamento. O benchmarking é uma ferramenta de gestão já adotada por alguns países nesse setor, visando à diminuição das perdas. $O$ presente artigo objetivou levantar informações sobre os modelos de aplicação dessa ferramenta, bem como comparar o desempenho entre os países onde há ou não a sua aplicação no âmbito do controle de perdas. Foi observado que o modelo ideal de estruturação de benchmarking capaz de minimizá-las inclui frequência de aplicação menor que anual, regulamentação parcial, confidencialidade ausente, gratuidade, relatórios públicos e restritos às prestadoras de serviço e interatividade média na demonstração dos resultados. Concluiu-se que os países onde o benchmarking é praticado possuem os melhores desempenhos referentes às perdas de água.

Palavras-chave: Saneamento; perdas de água; melhoria de desempenho; benchmarking.

Como citar: MARQUES, L. O. A.; CARVALHO, R. S., SA, M. O. M., MALHEIROS, T. F. Benchmarking enquanto Ferramenta de Diminuição das Perdas Físicas em Sistemas de Abastecimento de Água. Ambiente \& Sociedade. São Paulo, v. 24, p. 1-18, 2021. 


\title{
Benchmarking como herramienta para reducir las pérdidas físicas en los sistemas de suministro de agua
}

\author{
Luis Otavio do Amaral Marques \\ Rafael Santos Carvalho \\ Marcelo Otani Marques de Sa \\ Tadeu Fabrício Malheiros
}

São Paulo. Vol. 24, 2021

Dossier Especial:

Sustentare y Workshop Internacional sobre Indicadores de Sustent-
Resumen: En el contexto de las pérdidas en los sistemas de suministro de agua, los beneficios derivados de la reducción de sus índices influyen directamente en aspectos sociales, económicos y medioambientales, incluida la universalización de los servicios de saneamiento. El Benchmarking es una herramienta de gestión ya adoptada por algunos países, con el propósito de reducir las pérdidas. El objetivo de este trabajo es recopilar información sobre los modelos de aplicación de esta herramienta, así como comparar el rendimiento entre los países donde se aplica o no. Se observó que el modelo ideal de estructuración del benchmarking capaz de minimizar estos índices incluye frecuencia de aplicación inferior a la anual, regulación parcial, ausencia de confidencialidad, gratuidad, informes públicos y privados a proveedores de servicios e interactividad media en la cuenta de resultados. También se concluyó que los países donde se practica el benchmarking tienen los mejores rendimientos en cuanto a pérdidas.

Palabras-clave: sistema de suministro de agua, agua no contabilizada, mejora del rendimiento, benchmarking.

Como citar: MARQUES, L. O. A.; CARVALHO, R. S., SA, M. O. M., MALHEIROS, T. F. Benchmarking como herramienta para reducir las pérdidas físicas en los sistemas de suministro de agua. Ambiente $\mathbb{E}$ Sociedade. São Paulo, v. 24, p. 1-18, 2021. 